\title{
PERMAINAN PLASTISIN UNTUK MENINGKATKAN KEMAMPUAN MOTORIK HALUS ANAK KELAS B TK CAHAYA KASIH MODAYAG
}

\author{
Hellen F. Watulingas ${ }^{1}$, Mario Eric Wantah ${ }^{2}$ \\ Universitas Negeri Manado \\ e-mail: 1 hellen.thufuli@gmail.com, mariowantah@unima.ac.id,
}

Diterima: 19 April 2021 I Direvisi: 26 April 2021 I Disetujui: 27 April 2021 (C)2021

Pendidikan Guru Raudhatul Atfhal Fakultas Agama Islam Universitas Islam Malang

\begin{abstract}
The problem encountered at Cahaya Kasih Modayag Kindergarten is the lack of stimulating teachers for children to relax plasticine by squeezing, flattening, feeling, grinding in their fingers. The purpose of this study was to apply plasticine games by forming houses to improve fine motor skills in children at Cahaya Kasih Modayag Kindergarten. The research method is classroom action research (PTK). The subjects of this study were 13 children. The results of the discussion in the first cycle of research were: (31\%) because children were able to move their fingers in flattening plasticine. Meanwhile (8\%) because there is an increase in the radius. And (61\%) because children experience delays in moving their fingers. Then the researcher continued the second cycle (76\%) because the child was able to relax. Meanwhile (24\%) because the child is able to move his fingers so that it becomes an airplane shape.
\end{abstract}

Kata Kunci: Motorik halus, plastisin, membentuk pesawat.

\section{A. Pendahuluan}

Pendidikan anak usia dini merupakan wahana pendidikan yang sangat fundamental dalam memberikan kerangka dasar terbentuk dan berkembangnya dasar-dasar pengetahuan sikap dan keterampilan pada anak. Pendidikan Anak Usia Dini merupakan salah satu bentuk penyelenggaraan pendidikan yang menitikberatkan pada peletakan dasar ke arah pertumbuhan dan 5 bidang perkembangan, yaitu: perkembangan moral dan agama, perkembangan fisik (koordinasi motorik halus dan kasar), kecerdasan/kognitif (daya pikir,daya cipta), sosial emosional (sikap dan emosi), bahasa dan komunikasi, serta seni. Tentunya sesuai dengan keunikan dan tahap-tahap perkembangan sesuai kelompok usia dini seperti yang tercantum dalam PERMENDIKNAS no.58 tahun 2009, yaitu dengan tujuan membentuk anak Indonesia yang berkualitas, anak yang tumbuh dan 
berkembang sesuai dengan tingkat perkembangannya sehingga memiliki kesiapan yang optimal di dalam memasuki pendidikan dasar serta mengarungi kehidupan masa dewasa.

Motorik halus adalah hal penting dalam perkembangan anak usia dini. Saputra (2005), motorik halus adalah kemampuan beraktivitas dengan menggunakan otot-otot halus (kecil) seperti menulis, meremas, menggenggam, menggambar, menyusun balok dan memasukkan kelereng. Sejalan dengan Aisyah (2007: 4.39), perkembangan motorik halus halus meliputi penggunaan otot-otot kecil seperti jari-jari tangan.

Permainan plastisin harus memperhatikan kemampuan anak dan juga dapat menyenangkan dalam proses permainan dan menjadi tolak ukur dari efek permainan edukatif yang digunakan serta bentuk permainan plastisin tersebut sesuai dengan karakteristik anak usia dini. Menurut Sulyandari (2020) otot kecil berkembang setelah otot besar terlatih, maka dari itu, sebelum memberikan pelajaran tentng menulis, maka latihlah anak untuk melemaskan otot-otot besar dengan melukis bidang yang luar, kemudian latihlah otot-otot kecil anak dengan meremas dan atau berain plastisin.

Menurut Sumantri (2005: 9), tujuan pengembangan motorik anak meliputi motorik kasar dan motorik halus. Untuk tujuan pengembangan motorik halus adalah: a) mampu memfungsikan otot-otot kecil seperti gerakan jari tangan, b) mampu mengkoordinasikan kecepatan tangan dengan mata, c) mampu mengendalikan emosi.

Montesori (2013: 284) juga berpendapat bahwa, tujuan pembelajaran di TK adalah mengembangkan daya pikir anak sehingga penilaian dapat dilakukan ketika anak-anak telah melakukan sebuah pengamatan dan aktivitas, maka dalam penelitian ini dilakukan pada saat anak-anak melakukan aktivitas bermain yang didalamnya terdapat fokus pengembangan kognitif guna melatih kemampuan kreativitas anak.

Menurut Dockett (2000:41-43), bermain merupakan kebutuhan bagi anak karena melalui bermain anak akan memperoleh pengetahuan yang dapat mengembangkan kemampuan yang ada pada dirinya. Pada permainan lilin plastisin banyak aspek perkembangan anak yang dapat kita kembangkan, seperti aspek seni, disini anak mampu berimajinasi dengan apa yang ingin diciptakan, kemudian anak mampu untuk menentukan warna-warna yang akan membuat hasil karyanya lebih menarik dan anak dapat bereksperiman dengan menggabungkan berbagai macam warna yang dia inginkan, selanjutnya dalam melakukan kegiatan membuat hasil karyanya, motorik halusnya juga berkembang dalam membentuk sebuah karya yang diinginkan, dan anak mampu berpikir lebih tinggi lagi untuk membuat hasil 
karyanya lebih menarik (Montalalu, 2009:17) mengatakan bahwa dengan bermain plastisin ini, anak belajar menggiling, memipihkan dan merampingkannya, anak membagun konsep tentang benda, perubahannya, dan sebab akibat yang ditimbulkannya. Sejalan dengan pendapat Anderson (2010: 1), bermain dibutuhkan karena dapat menstimulus pertumbuhan anak diantaranya adalah menstimulus koneksi sel-sel syaraf, menstimulus fisik motorik kasar dan fisik motorik halus serta menstimulus perkembangan sosial dan bahasa anak. Bermain juga mengajarkan anak-anak untuk belajar mengomunika-sikan emosi, berpikir, kreatif dan mengatasi masalah. Maka dari itu pendidikan di TK sangatlah penting, hal ini diperkuat oleh pendapat Zaporozhets (dalam Leong dan Elena, 2012: 34) yang menyatakan bahwa, pendidikan prasekolah adalah cara untuk mengoptimalkan potensi peserta didik secara seimbang dan tidak bisa ditempuh dengan kelas akselerograf yang bertujuan mempersingkat masa kanak-kanak. Itulah uniknya prasekolah yang di dalamnya terdapat gambaran bagaimana anak bermain dan berinteraksi dengan teman sebaya serta orang dewasa.

Dalam permainan plastisin dapat mengkoordinasikan jari-jari tangan saat melakukan permainan ini, anak dituntut untuk meremas, membentuk, dan lain sebagainya. Sehingga motorik halus adalah gerakan yang hanya melibatkan bagianbagian tubuh tertentusaja dan dilakukan oleh otot-otot kecil seperti ketrampilan menggunakan jari-jemari tangan dan gerakan pergelangan tangan yang tepat (Sujiono, 2008:125). Permainan plastisin menggunakan model demontrasi karena model demonstrasi merupakan cara untuk menunjukkan dan menjelaskan caracara mengerjakan sesuatu. Menurut Muhibin (2000:222) bahwa demonstrasi adalah metode mangajar dengan cara memperagakan barang, kejadian, aturan, dan urutan melalui penggunaan media pengajaran yang relevan dengan pokok bahasan atau materi yang disajikan.

Permasalahan yang terjadi dalam permainan plastisin pada anak adalah dari jumlah 13 anak yang aktif dalam permainan plastisin, ada 4 anak yang mampu membentuk dengan plastisin melalui demonstrasi dari bentuk mengenal geometri seperti membentuk segitiga $(\Delta)$, segiempat( $\square$ ), lingkaran( $(0)$, sehinnga menjadi bentuk pesawat ataupun bentuk kreativitas yang lain sesuai imajinasi pada anak, serta menstimulasi anak aktif dalam mengembangkan permainan plastisin yang menyenangkan. Sedangkan 9 anak belum mampu membentuk plastisin dari bentuk mengenal geometri segitiga $(\Delta)$, segiempat( $\square)$, dan lingkaran( $(0)$, menjadi bentuk pesawat karena tahap perkembangan gerakan motorik halusnya mengalami keterlambatan dalam melemaskan plastisin dengan meremas, memipihkan, merasakan, menggiling dalam jari-jari tangannya, sehingga anak belum mampu membentuk dalam mengembangkan permainan plastisin yang menyenangkan,serta 
ide-ide yang kreatif dalam imajinasinya mengalami keterlambatan. Tujuan dari penelitian ini adalah Untuk menerapkan permainan plastisin dengan membentuk pesawat melalui model demonstrasi untuk meningkatkan kemampuan motorik halus pada anak di TK Cahaya Kasih Modayag.

\section{B. Metode}

Jenis penelitian ini adalah penelitian tindakan kelas (PTK) yang mengacu pada Kemmis dan Mc.Taggarat (dalam Aqib Zainal 2006:1) yang terdiri dari 4 tahapan yaitu:: perencanaan, tindakan/pelaksanaan, observasi, refleksi. Subjek dalam penelitian ini adalah anak usia 4-6 tahun sebanyak 13 anak yang terdiri dari 7 anak perempuan dan 6 anak laki-laki. Teknik pengumpulan data dalam penelitian ini adalah melalui observasi terhadap anak yang sedang belajar dan tes untuk mengukur taraf kompetensi yang bersifat keterampilan atau piskomotorik dimana penilaian dilakukan proses penyelesaian tugas dan hasil akhir yang dicapai oleh anak. Berdasarkan tingkat kemampuan anak dalam pembelajaran membentuk rumah dengan plastisin melalui model demonstrasi. Data yang diperoleh selama proses pembelajaran dianalisis dengan teknik presentase yang dikemukakan oleh Trianto (2010:241). Hasil analisis data, guna mengetahui anak dalam pelaksanaan pembelajaran untuk meningkatkan hasil pembelajaran melalui model demonstrasi. Pembelajran berhasil jika mencapai standar ketuntasan belajar yang berarti berkembang sangat baik.

\section{Hasil dan Pembahasan}

\section{Siklus I}

Hasil refleksi menunjukkan dari jumlah 13 anak, 4 anak (31\%) karena anak mampu membentuk dengan plastisin dari bentuk geometri $\boldsymbol{\Lambda}, \mathbf{\square}, \mathbf{O}$ ataupun bentuk kreativitas yang lain sesuai imajinasi pada anak, serta menstimulas anak aktif dalam mengembangkan permainan plastisin yang menyenangkan sehingga berkembang sangat baik. Sedangkan 9 anak yang terdiri dari 1 anak (8\%) mulai berkembang karena anak mampu menggerakkan jari-jari tanganya dalam melemaskan plastisin dengan melemaskan, menggiling dan memipihkan dalam bentuk geometri $\boldsymbol{\Lambda}, \mathbf{\square}, \mathbf{0}$ mulai ada peningkatan. Begitupun 8 anak (61\%) belum mampu membentuk plastisin dari bentuk mengenal geometri $\boldsymbol{\Lambda}, \mathbf{\square}, \mathbf{0}$ karena tahap perkembangan gerakan motorik halusnya mengalami keterlambatan dalam melemaskan plastisin dengan meremas, memipihkan, merasakan, menggiling dalam jari-jari tangannya sehingga anak belum bisa mengembangkan permainan plastisin yang 
menyenangkan serta ide-ide yang kreatif dalam imajinasinya anak belum berkembang dalam permainan plastisin yang menyenagkan.

Dengan Standar Ketuntasan Belajar pada siklus 1 belum mencapai hasil yang maksimal, karena itu peneliti melanjutkan pada putaran/siklus II.

\section{Siklus II}

Hasil penelitian siklus II menunjukkan dari jumlah 13 anak, ada 10 anak (76\%) mengalami peningkatan dalam membuat permainan plastisin dari bentuk mengenal geometri $\boldsymbol{\Delta}, \boldsymbol{\square}, \mathbf{O}$ menjadi bentuk rumah karena permainan edukatif yang menyenangkan serta menstimulus anak aktif dalam permainan plastisin dengan menggerakkan jar-jarinya berkembang sangat baik. Sedangkan 3 anak (24\%) berkembang sesuai harapan karena anak bisa membentuk geometri $\boldsymbol{\Lambda}, \boldsymbol{\square}, \boldsymbol{O}$ dalam perkembangan jari-jari tangannya anak mampu membentuk permainan plastisin yang menyenangkan, dengan hasil standar ketuntasan belajar maka tercapai secara optimal.

\section{PEMBAHASAN}

Berdasarkan hasil pada siklus I belum memenuhi Standar Ketuntasan Belajar. Hal ini dikarenakan kurangnya menstimulus anak sehingga mengalami keterlambatan dalam permainan plastisin dalam perkembangan gerakan motorik halus dalam melemaskan plastisin dengan meremas, memipihkan, merasakan dalam jari-jari tangannya sehingga anak belum mampu membentuk dalam mengembangkan permainan plastisin serta-ide ide kreatif dalam imajinasinya yang menyenangkan serta permainan yang kurang edukatif. Dengan masalah ini, maka peneliti melanjutkan pada siklus II.

Padahal menurut Kartini (2013: 26), anak usia TK adalah usia golden age (usia emas) karena seluruh aspek perkembangannya telah siap untuk dikembangkan dengan berbagai stimulus kegiatan. Aspek perkembangan tersebut meliputi nilai agama dan moral, bahasa, fisik motorik, seni dan kognitif yang saling terkait karena pembelajaran di TK menggunakan tematik terpadu. Sehingga harusnya anak telah mencapai tahap tersebut, karena aspek kreativitas belum nampak, maka peneliti melanjutkannya di siklus II.

Pembelajaran pada siklus II guru memperbaiki kekurangan-kekurangan pada siklus I seperti menyiapkan alat media/peraga yang lebih menarik dan guru lebih menguasai materi yang akan disampaikan dengan menggunakan model pembelajaran demonstrasi yang cocok dengan materi pembelajaran dan melibatkan anak langsung aktif pada pembelajaran sesuai dengan karakteristik dan potensi 
anak. Hal ini menunjukkan hasil belajar dari siklus I dari jumlah 13 anak, 4 anak (31\%) karena anak mampu membentuk dengan plastisin dari bentuk geometri bentuk $\boldsymbol{\Lambda}, \mathbf{\square}, \mathbf{O}$ ataupun bentuk kreativitas yang lain sesuai imajinasi pada anak, serta menstimulus anak aktif dalam mengembangkan permainan plastisin yang menyenangkan sehingga berkembang sangat baik. Sedangkan 9 anak yang terdiri dari 1 anak (8\%) mulai berkembang karena anak mampu menggerakkan jari-jari tanganya dalam melemaskan plastisin dengan melemaskan, menggiling dan memipihkan dalam bentuk geometri $\boldsymbol{\Lambda}, \boldsymbol{\square}, \mathbf{0}$. Begitupun 8 anak (61\%) belum mampu membentuk plastisin dari bentuk mengenal geometri $\boldsymbol{\Lambda}, \mathbf{\square}, \mathbf{0}$ karena tahap perkembangan gerakan motorik halusnya mengalami keterlambatan dalam melemaskan plastisin dengan meremas, memipihkan, merasakan, menggiling dalam jari-jari tangannya sehingga anak belum bisa mengembangkan permainan plastisin yang menyenangkan serta ide-ide yang kreatif dalam imajinasinya anak belum berkembang dalam permainan plastisin yang menyenagkan.

Selanjunya dilakukan pada siklus II yaitu : dari jumlah 13 anak, ada 10 anak (76\%) mengalami peningkatan dalam membuat permainan plastisin dari bentuk mengenal geometri $\boldsymbol{\Lambda}, \boldsymbol{\square}, \boldsymbol{O}$ menjadi bentuk rumah karena permainan edukatif yang menyenangkan serta menstimulus anak aktif dalam permainan plastisin dengan menggerakkan jar-jarinya berkembang sangat baik. Sedangkan 3 anak (24\%) berkembang sesuai harapan karena anak bisa membentuk geometri $\boldsymbol{\Lambda}, \mathbf{\square}, \boldsymbol{O}$ menjadi bentuk rumah dalam perkembangan jari-jari tangannya anak mampu membentuk permainan plastisin yang menyenangkan, dengan hasil standar ketuntasan belajar maka tercapai secara optimal.

\section{Simpulan}

Model demontrasi dapat meningkatkan hasil pembelajaran motorik halus dalam permainan plastisin dengan membentuk rumah sehingga mampu menstimulus ataupun menstimulasi pada anak. Model demontrasi dapat membantu anak lebih aktif dan kreatif dalam mengembangkan kreativitas melalui kegiatan membentuk dari plastisin sehingga anak mampu berimajinasi dalam permainan plastisin tersebut.

\section{Daftar Rujukan}

Aisyah, Siti. dkk. Pengembangan dan Konsep Pengembangan Anak Usia Dini.Jakarta: Universitas Terbuka. 
Hellen F. Watulingas ${ }^{1}$, Mario Eric Wantah²

Anderson Jona K. 2010. The Importance of Play in Early Childhood Development. Bozeman: Extension, (Online), (http://store.msuextension.org/publications/HomeHealthandFamily/MT201003HR.pdf), diakses 3 Februari 2014

Aqib Zainal. 2006. Penelitian Tindakan Kelas. Jakarta. Bandung: Irama Widya

Dockett and FleedMarily. 2000. Play and Pendagogy in Early Chidhood. AustraliziHorcout.

Leong, Deborah J. and Elena Bodrova. 2012. Assessing and Scaffolding Make-Believe Play. National Association for the Education of Young Children

Muhibin Syah. 2000. PsikologiBelajar. Jakarta : Raja GrafindoPersada.

Montesori, Maria. Tanpa Tahun. Metode Montesori. Terjemah Gutex, Gerald Lee. 2013. Yogyakarta: Pustaka Pelajar.

Montolalu B,E.F. 2009. Bermain dan PermainanAnak.Jakarta :Universitas Terbuka

PERMENDIKNAS. No.58 tahun 2009. Tentang Sistem Pendidikan Nasional. Jakarta : Depdiknas RI

Saputra, M. Y dan Rudyanto. 2005. Pembelajaran Kooperatif Untuk Meningkatkan Keterampilan Anak TK. Jakarta: Depdiknas.

Sujiono Bambang, dkk. 2009. Metode Pengembangan Fisik. Jakarta : Universitas Terbuka

Sumantri. 2005. Model Pengembangan Keterampilan Motorik Anak Usia Dini. Jakarta: Depdiknas.

Trianto.2010. Kriteria Ketuntasan Individu dan Klasikal Siswa. Bandung : Irama Widya

Sulyandari, Ari Kusuma. 2020. Pengembangan Sirkuit Bongkar Pasang untuk Aktivitas Fisik Motorik Kasar di Lembaga Prasekolah dengan Lahan Minimalis. Jurnal Seling: Jurnal Program studi PGRA. 6(2). (online) http://jurnal.stitnualhikmah. ac.id/index.php/seling/article/view/633 